Chapman University

Chapman University Digital Commons

Business Faculty Articles and Research

Business

2013

\title{
Staying Hungry, Staying Foolish: Academic Reflections on the Life and Career of Steve Jobs
}

Amy E. Hurley-Hanson

Chapman University, ahurley@chapman.edu

Cristina M. Giannantonio

Chapman University, giannant@chapman.edu

Follow this and additional works at: https://digitalcommons.chapman.edu/business_articles

Part of the Business Administration, Management, and Operations Commons, and the Leadership Studies Commons

\section{Recommended Citation}

Hurley-Hanson, A.E. \& Giannantonio, C.M. Staying Hungry, Staying Foolish: Academic Reflections on the Life and Career of Steve Jobs. Journal of Business and Management. 19, 2013, 7-10.

This Article is brought to you for free and open access by the Business at Chapman University Digital Commons. It has been accepted for inclusion in Business Faculty Articles and Research by an authorized administrator of Chapman University Digital Commons. For more information, please contact laughtin@chapman.edu. 
Staying Hungry, Staying Foolish: Academic Reflections on the Life and Career of Steve Jobs

\section{Comments}

This article was originally published in Journal of Business and Management, volume 19, issue 1, in 2013.

\section{Copyright}

Chapman University 


\title{
Staying Hungry, Staying Foolish: Academic Reflections on the Life and Career of Steve Jobs
}

\author{
Amy E. Hurley-Hanson \\ Chapman University \\ Cristina M. Giannantonio \\ Chapman University
}

\begin{abstract}
The 2011 death of Steve Jobs, Apple CEO and cofounder, generated a flood of articles in the popular press acknowledging his influence on the design and delivery of consumer products that changed the way multiple generations work and play. As one of the most visible, yet controversial CEOs in recent history, stories of his management style are likely to fuel a debate over his leadership effectiveness. It is expected that scholarly and academic articles will emerge in the next few years detailing the business lessons that can be learned from the way that Jobs ran Apple Computer, NeXT, Pixar, and his transformation of Apple in the 1990s.
\end{abstract}

Steve Jobs' personal story and business success reflect the American dream. The highs and lows of his career path embody the entrepreneurial spirit. From starting a business in his parents' garage to being the CEO of one of America's most highly valued companies, his story is the stuff of legends. His career included being fired and rehired by the company he founded, starting and selling several successful companies, and moving seamlessly between several industries and technologies. The purpose of this Special Issue is to offer academic reflections on the life and career of Steve Jobs and to initiate a scholarly discussion of research on entrepreneurial careers.

Few entrepreneurs have captured the world's attention as Steve Jobs did. His early career success, dramatic ouster from the company he built, and ultimate transformation of Apple into one of America's largest multibillion dollar companies encapsulates the American dream. The facts of his early life, including being given up at birth and being adopted by loving and supportive parents, provide us with a contemporary version of Horatio Alger's classic success stories. There is great interest in Jobs' life story with sales of Isaacson's biography reaching over 379,000 in its first week of publication. 
Issacson's biography was Amazon's top selling book of 2011 despite being published in the 4th quarter of the year (Lovecraft, 2011).

There is also much interest in Jobs' career path because of his many accomplishments at a young age. His untimely death left questions unanswered about the products he might have invented, what he might have accomplished later in life, his influence on the companies he created and what the later stages of his entrepreneurial career might have looked like. The papers in this Special Issue provide academic reflections on the life and career of Steve Jobs. They are meant to initiate a scholarly discussion of entrepreneurial careers and to suggest new research directions that bridge the entrepreneurial and careers literatures. The papers in this Special Issue were presented in a symposium we organized at the 2012 Academy of Management annual meetings in Boston, MA. This symposium was selected by the Academy Program Chair to be designated a Showcase Symposium. Symposia are selected for this distinction if the topic is judged to cut across and appeal to several Academy divisions, and if the symposium has the potential to draw a large audience. Five papers are included in this Special Issue.

Hurley-Hanson, Giannantonio, and Sudek explore the career path of high-tech entrepreneurs exemplified by Steve Jobs. They explore the later stages of his career, starting with his return to Apple and his efforts to reconnect Apple to its core strength, innovation. Hurley-Hanson, Giannantonio, and Sudek argue that entrepreneurial careers do not fit traditional stage models of career development. They propose a model of entrepreneurial careers that describes career stages that are more appropriate to the career paths of high-tech entrepreneurs, introduce the concept of career phases, and discuss the role that age plays in entrepreneurial careers. Each of the papers included in this Special Issue examine one of the four career stages they propose.

Stephen Carroll explores reconnection, the first stage of the career model outlined by Hurley-Hanson, Giannantonio, and Sudek. Carroll argues that Steve Jobs was a persuasive leader who used numerous elements from the Arts to convince people of his vision to reconnect Apple to its primary purpose: making great products. Carroll details the techniques and tools of artists that Jobs incorporated into presentations to persuade and convince his followers of the obtainability of his vision. He likens Jobs' carefully crafted product launches (called Keynotes at Apple) to an actor performing on the stage.

Howard $\mathrm{Yu}$ explores transformation, the second stage in Hurley-Hanson, Giannantonio, and Sudek's model. Yu explores how Jobs transformed Apple by describing how his leadership style can be "decoded" into a series of replicable managerial practices that other organizations can emulate. More specifically, he explores what practices other companies can potentially adopt to achieve the same level of impact that Apple has created on the technological informal economy.

Julia Richardson and Mike Arthur examine the reflection stage of Steve Jobs' life and career. They focus on Steve Jobs' commencement address to the Stanford University graduating class of 2005. In this speech, Steve Jobs reflected on his experiences, his successes, and his failures in the hope of having an impact on the graduates' careers and lives. Richardson and Arthur explore the career lessons included in the speech. They connect each of his three stories, "connecting the dots," "love and loss," and "death" with a range of messages about effective career behavior. They use these career lessons to illustrate ideas about project-based careers, retrospective sense-making, and identity. 
Jeff Sonnenfeld examines the death stage of Steve Jobs' life and career. He explores how Jobs' death affected Apple's customers, Apple's executive team, and Apple's profitability. He also describes the issues associated with having Jobs' identity be so intertwined with Apple and how this may be a factor in the decline of Apple shares. Sonnenfeld also describes Steve Jobs' role as a folk hero in our society. He shows the similarity of Jobs to other folk heroes and industrial leaders in the past. Sonnenfeld illustrates the issues that other firms have faced with their hero's farewell, and examines how companies have dealt with this loss both successfully and unsuccessfully. Finally, Sonnenfeld discusses the problems associated with trying to find an identical replacement for Steve Jobs, and the realization that these types of folk heroes and leaders cannot be cloned.

\section{... And one more thing}

We hope that this Special Issue on Steve Jobs' entrepreneurial career will initiate a scholarly discussion that will contribute to our understanding of high-tech entrepreneurial careers. As might be expected, Jobs had an opinion about this. In an April 20, 1995 Smithsonian Institution oral interview he stated, "I'm convinced that about half of what separates the successful entrepreneurs from the non-successful ones is pure perseverance." It's our job to find that other fifty percent.

Stay Hungry. Stay Foolish. 